\title{
Development and Validation of an Ion Chromatography Method for the Simultaneous Determination of Seven Food Additives in Cheeses
}

\author{
Marco Iammarino*, Aurelia Di Taranto
}

Istituto Zooprofilattico Sperimentale della Puglia e della Basilicata, Foggia, Italy.

Email: *marco.iammarino@tin.it

Received October $4^{\text {th }}, 2013$; revised November $4^{\text {th }}, 2013$; accepted November $11^{\text {th }}, 2013$

Copyright (C) 2013 Marco Iammarino, Aurelia Di Taranto. This is an open access article distributed under the Creative Commons Attribution License, which permits unrestricted use, distribution, and reproduction in any medium, provided the original work is properly cited.

\begin{abstract}
Cheeses are characterized by several chemical-physical properties that make it difficult for the microorganisms growth, consequently. The actual European legislation allows the addition of few food additives in this type of food products. In this work, the entire procedure of extraction, purification, chromatographic separations and quali/quantitative determination of seven food additives (sorbic acid, benzoic acid, lactic acid, acetic acid, nitrites, nitrates and phosphates) was developed and applied for the analysis of different types of cheese (mozzarella, cheese spread, semi-hard and hard cheeses). Through validation procedure it was possible to evaluate the most important validation parameters. Extended calibration curves $(r>0.990)$ were obtained for all the analyzed compounds. Recovery values ranged from $72.8 \%$ to $98.4 \%$ and a good repeatability was obtained, with precision levels in the range of $0.03 \%-0.11 \%(n=6)$. The potential and feasibility of the method were tested by analysing real samples, such as mozzarella, cheese spread, semi-hard and hard cheeses, confirming that the method is well suited to satisfy the demands for accurate confirmation analyses of seven food additives in cheeses, which is especially valuable in official check analyses and in monitoring schemes.
\end{abstract}

Keywords: Dairy Products; Cheese; Food Additives; Food Preservatives; Nitrites; Nitrates; Ion Chromatography; Validation

\section{Introduction}

Dairy products are characterized by several chemicalphysical properties that make it difficult for the microorganisms growth. These characteristics are low water activity, low $\mathrm{pH}$, high concentration of sodium chloride, lacking of fermentescible carbohydrates and the possible presence of batteriocins produced by microbial starters and/or of anaerobic condition [1]. These conditions do not make it necessary to the addition of particular food additives, in particular preservatives, in this type of food products; consequently, the actual legislation allows the addition of few food additives in dairy products (Table 1). Among these additives, the most used ones are two preservatives (with some restrictions, see Table 1): sorbic acid and nitrates, and three acidity regulators: lactic acid, acetic acid and phosphates. Another two important food

${ }^{*}$ Corresponding author. preservatives, benzoic acid and nitrites, are not admitted [2], but they are considered in this study due to their toxicity and large use in many foodstuffs. In several foodstuffs the contrast action towards different microorganisms, yeast and moulds is exercised through the addition of a mixture of sorbic acid and benzoic acid [3]. The first one cannot be considered as harmful for humans since it can be metabolized like caproic acid [4,5]. For this reason, some limits of use related to sorbic acid are particularly high (up to $2000 \mathrm{mg} \cdot \mathrm{kg}^{-1}$ in processed cheeses). As it concerns benzoic acid, it may be considered harmless for humans, at employment doses, because it is not accumulated, but completely eliminated by urine as hippuric acid [6-8]. Nevertheless, high doses of benzoic acid (until to $1000 \mathrm{mg} \cdot \mathrm{day}^{-1}$ ) may cause oesophagus burning, nausea and headache [9]; moreover, it causes occasional allergic reactions (hives, dermatitis, rhinitis, etc.) in sensitive persons [10]. For these reasons an acceptable daily 
Table 1. Food additives analysed and relating legal limits.

\begin{tabular}{|c|c|c|c|}
\hline Food additive & E-number & Legal limit $\left(\mathrm{mg} \cdot \mathrm{kg}^{-1}\right)$ & Restrictions \\
\hline \multirow{3}{*}{ Sorbic acid—sorbates } & \multirow{3}{*}{ E200, 202, 203} & 1000 & $\begin{array}{l}\text { Only cheese, prepacked, sliced and cut; layered cheese and } \\
\text { cheese with added foods }\end{array}$ \\
\hline & & quantum satis & Only ripened products surface treatment \\
\hline & & 2000 & Processed cheese \\
\hline Acetic acid & E260 & quantum satis & Only mozzarella and whey cheese \\
\hline Benzoic acid—benzoates & $\mathrm{E} 210,211,212,213$ & Not admitted & - \\
\hline Lactic acid & $\mathrm{E} 270$ & quantum satis & Only mozzarella and whey cheese \\
\hline Nitrites & $\mathrm{E} 249,250$ & Not admitted & - \\
\hline Nitrates & $\mathrm{E} 251,252$ & 150 & Only hard, semi-hard and semi-soft cheese \\
\hline \multirow{2}{*}{$\begin{array}{l}\text { Phosphoric acid-phosphates } \\
\text { di-tri and polyphosphates }\end{array}$} & \multirow{2}{*}{$\begin{array}{l}\mathrm{E} 338,339,340,341 \\
\quad 450,451,452\end{array}$} & 2000 & Only unripened products except mozzarella \\
\hline & & 20,000 & Processed cheese \\
\hline
\end{tabular}

intake (ADI) for benzoic acid, equal to $0-5 \mathrm{mg} \cdot \mathrm{kg} \mathrm{bw}$, was established [11] and this food preservative was deleted from the list of authorized food additives in dairy products, since it was considered unnecessary. It is important to underline that the actual legislation indicates that a quantifiable amount of this substance may be detected in certain fermented products resulting from the fermentation process following good manufacturing practice. Consequently, recent studies have deepened the dairy products characteristic and a maximum admissible limit for benzoic acid in cheeses was proposed [12]. Among the most common food preservatives, nitrites and nitrates are well-known due to their large use in meat curing. Notoriously, these food additives are harmful for humans. They may cause methemoglobinemia, which is the pathology due to reaction between nitrates, haemoglobin and myoglobin resulting in the synthesis of methaemoglobin and metmyoglobin [13-15]. Moreover, the reaction between secondary amines and nitrous acid, deriving from nitrates, brings about the synthesis of N-nitroso compounds that are notorious carcinogenic agents [16]. In the actual European Legislation, only nitrates are admitted in dairy products, limited to hard, semi-hard and semi-soft cheese; the limit of use is equal to $150 \mathrm{mg} \cdot \mathrm{kg}^{-1}$. For lactic acid, acetic acid and phosphates, there are no legal limits established by the actual Normative (lactic acid and phosphates are naturally present in dairy products). This is due to not-toxicity of these compounds at the employment doses. However it is compulsory to indicate the addition of these food additives on the product label [17], moreover, high intakes of phosphates may cause significant decreases in some oligoelements absorption [18] and they have been correlated with the bile ducts stones pathogenesis [19]. Actually, an analytical confirmatory method for the simultaneous determination of these food additives in cheeses is not available, consequently, in this work, the entire procedure of extraction, purification, chromatographic separations and quali/de- termination of seven food additives (sorbic acid, benzoic acid, lactic acid, acetic acid, nitrites, nitrates and phosphates) (Figure 1) was developed and applied for the most common types of cheeses (mozzarella cheese, cheese spread, semi-hard and hard cheese). The analytical method was fully validated following an in-house validation model according to European Regulations and then evaluating the most important validation parameters.

\section{Materials and Methods}

\subsection{Chemicals}

Lactic acid solution ( $\geq 85 \%$ ), acetic acid $(\geq 99.7 \%)$, potassium phosphate tribasic $(\geq 98 \%)$, nitrite ion standard solution $\left(1000 \mathrm{mg} \cdot \mathrm{L}^{-1}\right)$, nitrate ion standard solution $(1000$ $\left.\mathrm{mg} \cdot \mathrm{L}^{-1}\right)$, sorbic acid $(\geq 99 \%)$ and benzoic acid $(\geq 99.5 \%)$ were purchased from Sigma-Aldrich (Stenheim, Germany). Sodium carbonate anhydrous $(\geq 99.5 \%)$ and sodium hydroxide $(50 \% \mathrm{w} / \mathrm{w})$ were supplied by J. T. Baker (Deventer, Netherlands). All solutions used for ion-exchange chromatography were prepared with ultrapure water (minimal resistance $18.2 \mathrm{M} \Omega-\mathrm{cm}$ ), supplied by Milli-Q RG unit from Millipore (Bedford, MA, USA). Sodium carbonate solutions used as eluents were prepared by dilution in ultrapure water, degassing with nitrogen. The samples used for validation procedure were collected in local stores and they were characterized by the absence of food additives declared on the label. The sample fortified for accuracy tests (precision and recovery) was a semi-hard cheese produced with raw milk of cow origin, characterized by a ripening time of 8 months. The samples used for ruggedness evaluation were 4 mozzarella cheeses ( 2 from cow milk and 2 from buffalo milk), 4 different brands of cheese spreads and 4 hard cheeses ( 2 produced with raw milk of sheep origin, 1 with pasteurized milk of cow origin and 1 with raw milk of goat origin). They were characterized by ripening times ranging from 16 to 18 months. 


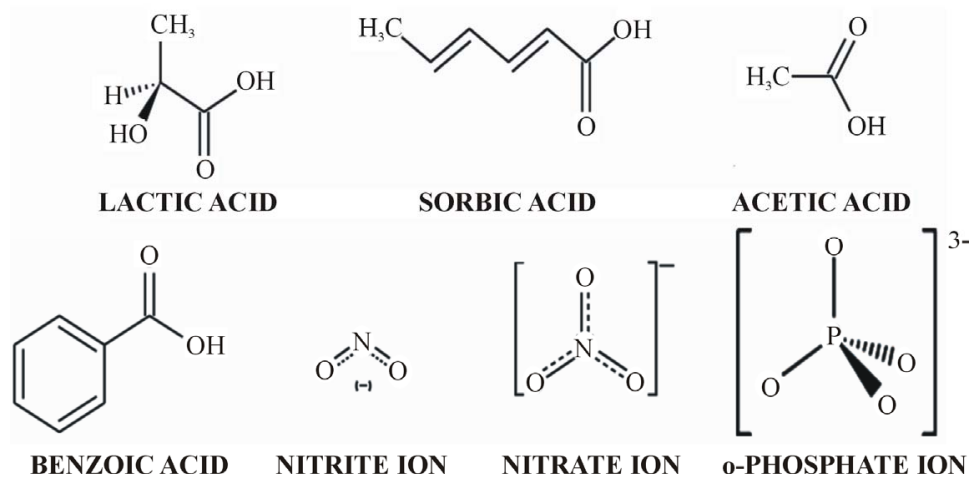

Figure 1. Structures of seven food additives analysed.

\subsection{Instrumentation}

All chromatographic determinations were performed on a Dionex HPLC system DX500 (Dionex Corporation, Sunnyvale, CA) equipped with an electrochemical detector (model ED40) fit to conductivity mode, a temperature compensated conductivity cell, a GP50 quaternary gradient pump, an injection loop $(25 \mu \mathrm{L})$ and a Rheodyne injection valve (model RH9125, Cotati, CA, USA). A Dionex anion self-regenerating suppressor (ASRS II, $4 \mathrm{~mm}$ ) was used for electrochemical suppression at an operating current of $50 \mathrm{~mA}$. The chromatographic separations were accomplished by using an anion-exchange column IonPac ${ }^{\circledR}$ AS9-HC (250 mm $\times 4$ mm i.d., particle size: $9 \mu \mathrm{m}$, Dionex Corporation, Sunnyvale, CA) eluted in gradient mode at a flow rate of 1.0 $\mathrm{mL} \cdot \mathrm{min}^{-1}$. The mobile phase consisted of $0.9 \mathrm{mM}$ $\mathrm{Na}_{2} \mathrm{CO}_{3}$ (A) and $28.5 \mathrm{mM} \mathrm{Na} \mathrm{CO}_{3}$ (B). The experimental separation conditions involved a multilinear gradient operating at room temperature and consisting of a linear gradient from $0.9 \mathrm{mM}$ to $3.7 \mathrm{mM}$ in 5 minutes, from 3.7 $\mathrm{mM}$ to $9.2 \mathrm{mM}$ in $1 \mathrm{~min}$, an isocratic step for 19 minutes, then a linear gradient from $9.2 \mathrm{mM}$ to $28.5 \mathrm{mM}$ in 1 minute and 4 minutes at this eluent concentration. The system was then re-equilibrated for $10 \mathrm{~min}$ at the initial $\mathrm{Na}_{2} \mathrm{CO}_{3}$ concentration. The mobile phase reservoir bottles (DX500 2 L bottles, Dionex) were closed and pressurized with pure nitrogen to $0.8 \mathrm{MPa}$. The system was interfaced via software (PeakNet ${ }^{\mathrm{TM}}$, Dionex Corporation, Sunnyvale, CA) to a personal computer for instrumentation control, data acquisition and processing.

\subsection{Sample Preparation}

A 4-g portion of sample, homogenized by blade ho-mogenizer, was placed in a Falcon tube and mixed with 40 $\mathrm{mL}$ of a $\mathrm{NaOH} 8.5 \times 10^{-3} \mathrm{M}$ solution. This particular solution allows an optimal analytes extraction from matrix, moreover it is essential for the preparation of standard solutions because it brings about an increment of method sensibility (by increasing acids dissociation) and it makes more neutral the solution $\mathrm{pH}$, stabilising the nitrite ion.

The extraction was obtained by placing the tube in ultrasonic bath (Transsonic Digitals, Elma Instruments, Singen, Germany. Ultrasound power: 80\%; Heating: $40^{\circ} \mathrm{C}$ ) for 10 minutes and then vortexing (Digital vortex mixer, VWR Int., Milan, Italy) for 1 minute. The sample purification was carried out through a centrifugation (Jouan BR4i centrifuge, Thermo Fisher, Milan, Italy. Speed: $1500 \times \mathrm{g}, 10$ minutes at room temperature) and a filtration of $\sim 5 \mathrm{~mL}$ of supernatant with Minisart ${ }^{\circledR} \mathrm{GF}$ syringe filters $(0.2 \mu \mathrm{m}$, Sartorius AG, Goettingen, Germany). A final removing of excess chlorides is necessary. This was obtained through a purification of $\sim 1 \mathrm{~mL}$ of filtrate with OnGuard II Ag chromatography filters (Dionex Corporation, Sunnyvale, CA) previously activated with $1 \mathrm{~mL}$ of ultrapure water, prior to chromatographic analysis (injection volume: $25 \mu \mathrm{L}$ ).

\subsection{Method Validation}

The optimized analytical method was submitted to a validation procedure, following an in-house validation model developed according to the Regulation No. 882/ 2004/EC [20] and Decision No. 657/2002/EC [21]. These Regulations describe the analytical parameters to appraise in order to assure the method reliability. These parameters are linearity, detection and quantification limits (LOD and LOQ), selectivity, accuracy (precision and recovery), ruggedness and measurement uncertainty.

Method linearity was verified by injecting 5 standard solutions, obtained by diluting the stock solution (100.0 $\mathrm{mg} \cdot \mathrm{L}^{-1}$ lactic acid, acetic acid, nitrites, nitrates and phosphates, $1000.0 \mathrm{mg} \cdot \mathrm{L}^{-1}$ Benzoic Acid and $2000.0 \mathrm{mg} \cdot \mathrm{L}^{-1}$ sorbic acid) with $\mathrm{NaOH} 8.5 \times 10^{-3} \mathrm{M}$.

The limit of determination (LOD) and quantification (LOQ) were elaborated according to Miller \& Miller [22]: $\mathrm{LOD}=3.3 \mathrm{~s}_{\mathrm{a}} / \mathrm{b}$ and LOQ $=10 \mathrm{~s}_{\mathrm{a}} / \mathrm{b}$, where $\mathrm{s}_{\mathrm{a}}$ is the standard deviation of the intercept and $b$ is the slope of the regression line obtained from the calibration curve. 
The selectivity is the method capacity to distinguish the analytes from other matrix components. This parameter was investigates through the analyses of twenty samples of cheeses (five mozzarella cheeses, five cheese spreads, five semi-hard cheeses and five hard cheeses) and verifying the absence of interfering peaks in the retention time-window of interest $( \pm 2.5 \%$ of the retention time of each analyte). It is important to underline that lactic acid and phosphate are substances naturally present in dairy products, consequently, for these additives, the selectivity was evaluated indirectly through accuracy tests.

Method accuracy (precision and recovery) was evaluated by analysing 6 cheese samples spiked with stock solution to obtain final concentrations equal to 20.0 $\mathrm{mg} \cdot \mathrm{kg}^{-1}$ in lactic acid, $20.0 \mathrm{mg} \cdot \mathrm{kg}^{-1}$ in acetic acid, 400.0 $\mathrm{mg} \cdot \mathrm{kg}^{-1}$ in sorbic acid, $20.0 \mathrm{mg} \cdot \mathrm{kg}^{-1}$ in nitrites, 200.0 $\mathrm{mg} \cdot \mathrm{kg}^{-1}$ in benzoic acid, $20.0 \mathrm{mg} \cdot \mathrm{kg}^{-1}$ in nitrates and $20.0 \mathrm{mg} \cdot \mathrm{kg}^{-1}$ in phosphates. For lactic acid and phosphates, that are naturally present in dairy products, the concentrations obtained by analysing the "blank" sample (not spiked) were subtracted from those obtained from spiked samples.

Method ruggedness was ascertained under major changes conditions toward different types of cheeses (mozzarella, cheese spread, semi-hard and hard cheeses) by using the Youden factorial experimental design [23].

Finally, the measurement uncertainty for each food additive was calculated by using the bottom-up method together with validation data obtained from each step of the analytical procedure [24]. The final values were obtained by the following equation:

$$
\bar{u}=\sqrt{(\bar{u}(C))^{2}+\left(\bar{u}\left(V_{f}\right)\right)^{2}+(\bar{u}(w))^{2}}
$$

where $\bar{u}$ indicates the relative uncertainty, $V_{f}$ is the volume of final extract, and $w$ is the sample weight. Four sources of uncertainty were considered for the determination of $\bar{u}(C)$ : (a) standards preparation; (b) repeatability; (c) recovery; (d) calibration curve.

\section{Results and Discussion}

\subsection{Method Oprimization}

The ion chromatography method for the simultaneous determination of seven food additives in cheeses was optimized starting from a chromatographic separation of organic acids proposed by Dionex Corporation [25]. The optimized gradient elution guaranteed a good resolution of analytes towards endogenous interfering peaks and a good retention time repeatability for each analyte $(<0.5 \%$, $\mathrm{n}=6$ ).

Different solutions, to use both for standards dilution and for samples extraction, were tested. The most impor- tant analytical problem to solve was the nitrites oxidation to nitrates due to the contemporary presence of different acids in the mixture [26]. It is not possible to use buffer solutions, since they cause an increase of interfering signals that compromise method selectivity. In order to basify the solution, $\mathrm{NaOH}$ solutions at different concentrations were tested. The best analytes stability (one week) was obtained by using $\mathrm{NaOH} 8.5 \times 10^{-3} \mathrm{M}$ compared to $\mathrm{NaOH} 8.5 \times 10^{-2} \mathrm{M}, \mathrm{NaOH} 8.5 \times 10^{-4} \mathrm{M}$ and ultrapure water. Another analytical problem was the high chlorides concentration of this type of food product that represents an important chromatographic interference for sorbic acid. This inconvenience was solved by using OnGuard II Ag chromatography filters (Dionex Corporation, Sunnyvale, CA) that remove about $90 \%$ of total chlorides and make possible the identification of sorbic acid.

\subsection{Method Validation}

The most important validation parameters appraised through validation procedure are reported in Table 2.

All calibration curves showed a determination coefficient $\left(\mathrm{r}^{2}\right)$ higher than 0.990 . This parameter together with evaluation of intercept (not significantly different from 0 ), of slope $\left(\mathrm{t}_{\mathrm{s}} / \mathrm{b}<0.22\right)$ and of Mandel's test (linear regression preferable to quadratic) confirmed method linearity for the food additives considered [27]. In Figure 2 a chromatogram related to an injection of a standard solution is shown.

As it concerns limits of detection, the lower values were obtained for lactic acid (LOD and LOQ equal to 0.6 and $1.9 \mathrm{mg} \cdot \mathrm{kg}^{-1}$ respectively) whereas the highest values were registered for sorbic acid (LOD and LOQ equal to 59.4 and $196.0 \mathrm{mg} \cdot \mathrm{kg}^{-1}$ respectively). These high values related to sorbic acid do not represent a weakness of this method, since the established legal limits for this food additive in dairy products are relatively high (up to 2000 $\mathrm{mg} \cdot \mathrm{kg}^{-1}$ ); subsequently, there is no necessity to reach high method sensibility.

No interfering peaks were observed by analysing twenty samples of cheeses (mozzarella cheeses, cheese spreads, semi-hard cheeses and hard cheeses), so, method selectivity was verified for acetic acid, sorbic acid, benzoic acid, nitrites and nitrates. For lactic acid and phosphates, method selectivity was assured through accuracy tests.

Method accuracy (precision and recovery) was evaluated by injecting 6 spiked samples. Precision was evaluated as CV\%, obtaining values in the range $3.0 \%-10.9 \%$. Recovery percentages were in the range $72.8 \%-98.4 \%$. Since there are no established reference values for the evaluation of accuracy of an analytical method for the determination of food additives in food products, the obtained values were compared with those reported in 
Table 2. Analytical method validation parameters.

\begin{tabular}{ccccccc}
\hline Food additive & Linearity $\left(\mathbf{r}^{\mathbf{2}}\right)$ & Specificity & $\begin{array}{c}\mathbf{L O D}^{\mathbf{a}} \\
\mathbf{m g} \cdot \mathbf{k g}^{-\mathbf{1}} \\
\text { in the sample }\end{array}$ & $\begin{array}{c}\mathbf{L O Q}^{\mathbf{b}} \\
\mathbf{m g} \cdot \mathbf{k g}^{-\mathbf{1}} \\
\text { in the sample }\end{array}$ & Recovery (\%) & $\begin{array}{c}\mathbf{C V \%} \\
(\mathbf{n}=\mathbf{6})\end{array}$ \\
\hline $\begin{array}{c}\text { Lactic acid } \\
\text { Acetic acid }\end{array}$ & 0.992 & - & 0.6 & 1.9 & 92.3 & 9.4 \\
Sorbic acid & 0.998 & No interferences & 3.6 & 11.9 & 79.6 & 3.0 \\
$\quad$ Nitrite & 0.990 & No interferences & 59.4 & 196.0 & 72.8 & 10.2 \\
Benzoic acid & 0.994 & No interferences & 2.8 & 9.3 & 78.6 & 10.3 \\
$\quad$ Nitrate & 0.997 & No interferences & 16.5 & 54.5 & 95.0 & 7.0 \\
Phosphate & 0.997 & No interferences & 2.1 & 6.8 & 88.1 & 10.9 \\
\hline
\end{tabular}

${ }^{\mathrm{a}}$ Limit of Detection. ${ }^{\mathrm{b}}$ Limit of Quantification. ${ }^{\mathrm{c}}$ Coefficient of Variation.

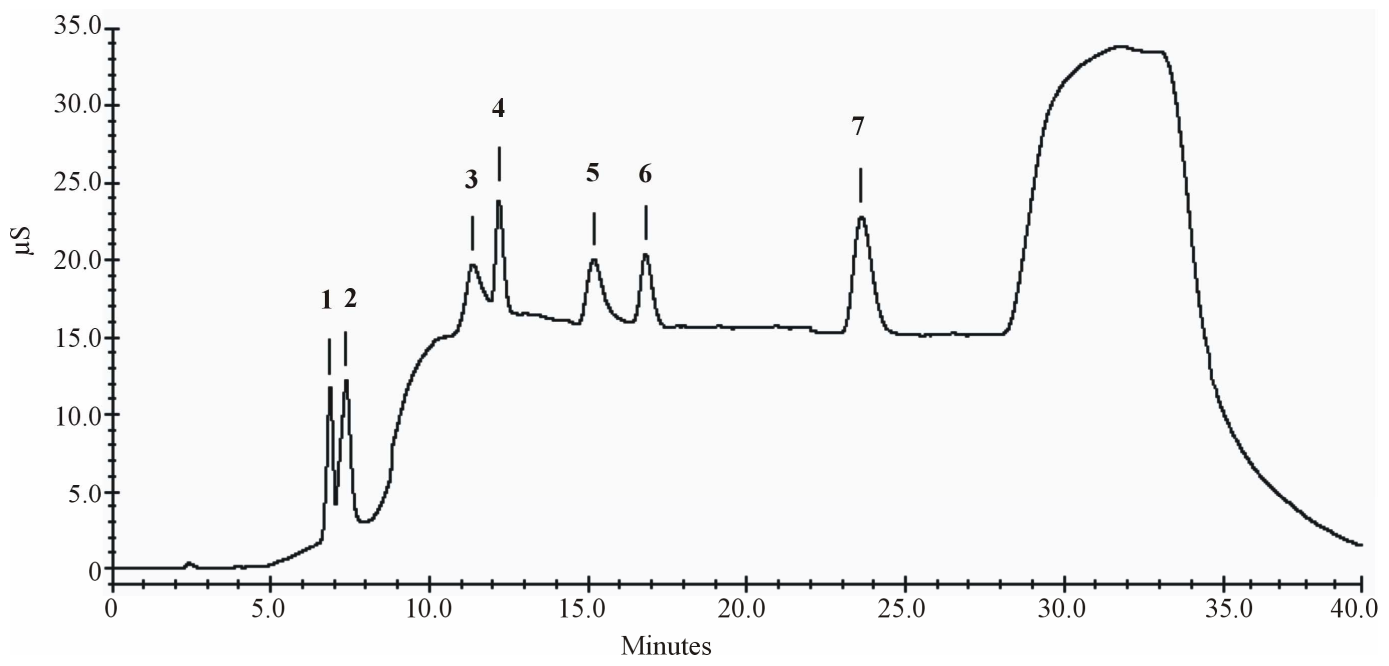

Figure 2. Chromatogram of a standard solution. (1): lactic acid (5.0 mg. $\left.\mathbf{L}^{-1}\right)$, (2): acetic acid (5.0 mg. $\left.\mathbf{L}^{-1}\right)$, (3): sorbic acid $\left(100.0 \mathrm{mg} \cdot \mathrm{L}^{-1}\right)$, (4): nitrites $\left(5.0 \mathrm{mg} \cdot \mathrm{L}^{-1}\right)$, (5): benzoic acid $\left(50.0 \mathrm{mg} \cdot \mathrm{L}^{-1}\right)$, (6): nitrates $\left(5.0 \mathrm{mg} \cdot \mathrm{L}^{-1}\right)$, (7): phosphates $(5.0$ $\left.\mathbf{m g} \cdot \mathbf{L}^{-1}\right)$.

Decision No. 657/2002/EC, resulting substantially conform. In Figures 3 and $\mathbf{4}$ comparisons between cheese samples spiked with a standard solution and not-spiked are shown.

Method ruggedness under major changes conditions was evaluated by using Youden factorial experimental design. Different sets of real samples: 4 mozzarella cheeses, 4 cheese spreads, 4 semi-hard cheeses and 4 hard cheeses, spiked at the same fortification level used for accuracy tests. The seven factors chosen as variables for Youden test were the matrix and six fictitious factors. The Youden experimental design requires twelve independent experiments: four with validation matrix (semihard cheese) and four with each alternative matrices. The results obtained for each alternative matrix, expressed as standard deviation of difference $\mathrm{S}_{\mathrm{Di}}$ of each food additive, were lower than the estimated method precision (evaluated as twice the repeatability standard deviation). These results confirmed that the matrix variation does not com- promise the analytical performances and, consequently, the method is applicable to mozzarella cheese, cheese spread, semi-hard and hard cheese samples.

Measurement uncertainty was calculated for each analyte. The obtained values were in the range $8.6 \%-12.7 \%$, confirming method reliability.

\subsection{Real Samples Analyses}

In order to confirm the reliability of described analytical method, 20 different types of cheese samples (8 mozzarella, 6 cheese spreads, 3 semi-hard cheeses and 3 hard cheeses) were collected in local stores and analysed. No food additives were declared on the label of these samples (except for two mozzarella samples in which citric acid was added). Quantifiable amounts of nitrites, sorbic acid, acetic acid and benzoic acid were not registered. Nitrates quantifiable amounts were detected in two samples: a semi-hard cheese $\left(23.6 \mathrm{mg} \cdot \mathrm{kg}^{-1}\right)$ and a hard cheese sample $\left(11.5 \mathrm{mg} \cdot \mathrm{kg}^{-1}\right)$. The presence of quantifi- 


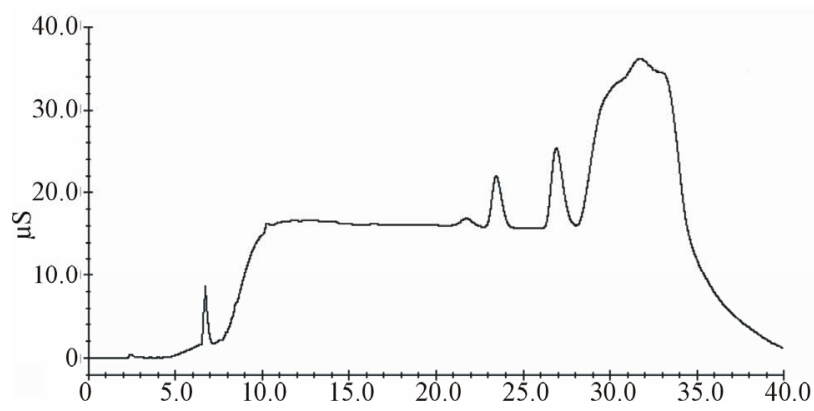

(a)

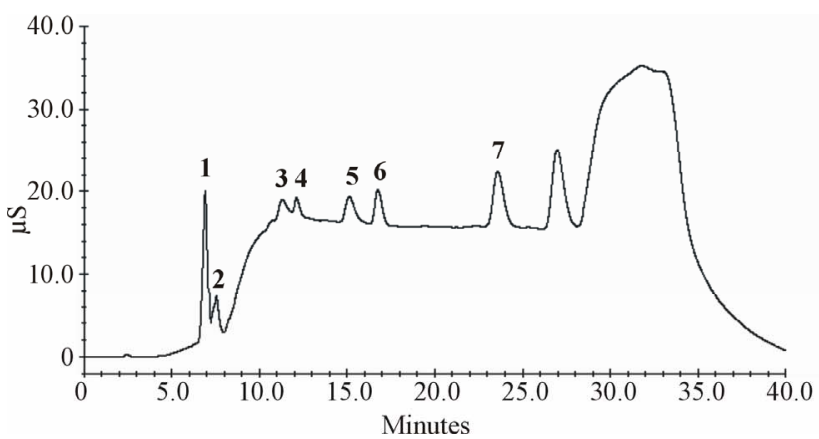

(b)

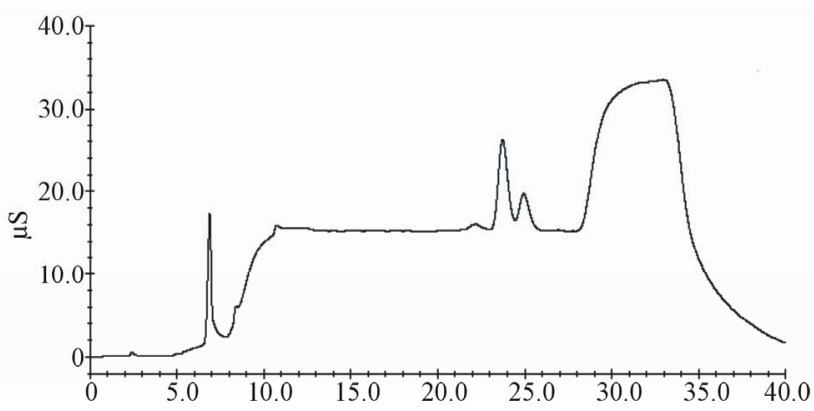

(c)

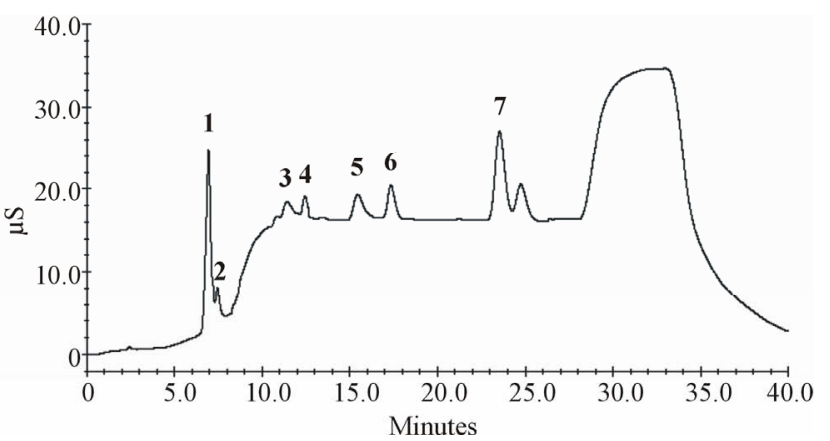

(d)

Figure 3. Chromatograms comparison between spiked samples (lactic acid $20.0 \mathrm{mg} \cdot \mathrm{kg}^{-1}$, acetic acid $20.0 \mathrm{mg} \cdot \mathrm{kg}^{-1}$, sorbic acid $400.0 \mathrm{mg} \cdot \mathrm{kg}^{-1}$, nitrites $20.0 \mathrm{mg} \cdot \mathrm{kg}^{-1}$, benzoic acid $200 \mathrm{mg} \cdot \mathrm{kg}^{-1}$, nitrates $20.0 \mathrm{mg} \cdot \mathrm{kg}^{-1}$, phosphates $20.0 \mathrm{mg} \cdot \mathrm{kg}^{-1}$ ) and not-spiked: Not-spiked Mozzarella cheese (a); Spiked Mozzarella cheese (b); Not-spiked cheese spread (c); Spiked cheese spread (d).

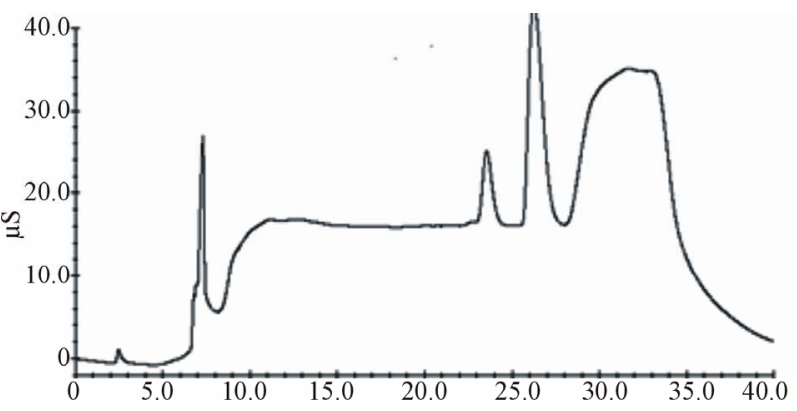

(a)

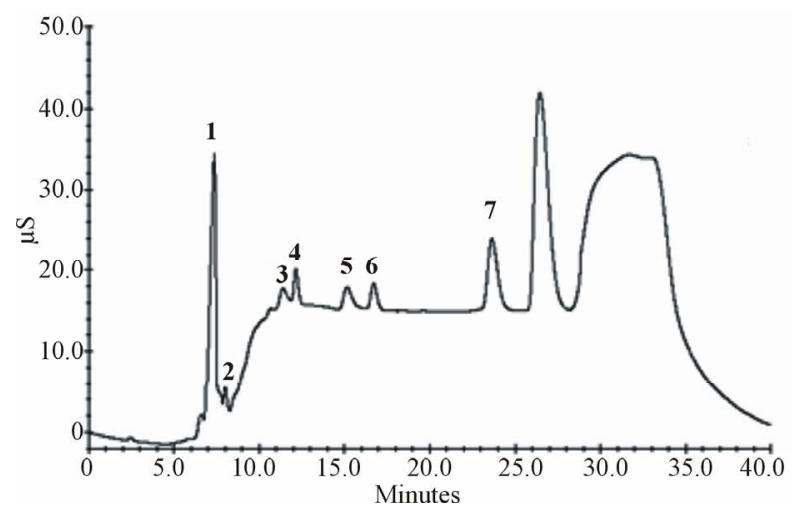

(b)

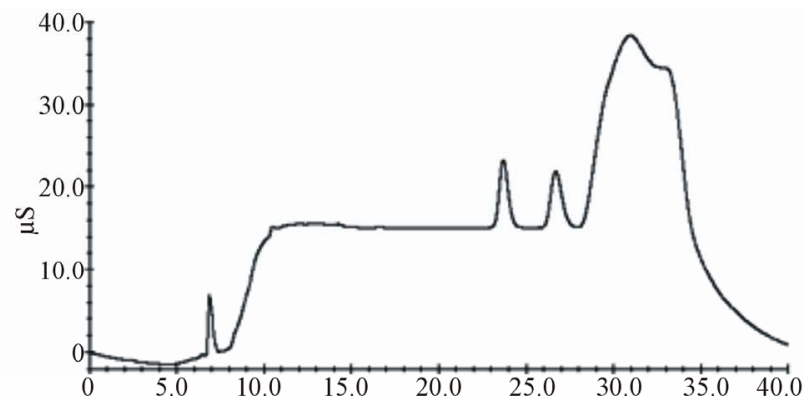

(c)

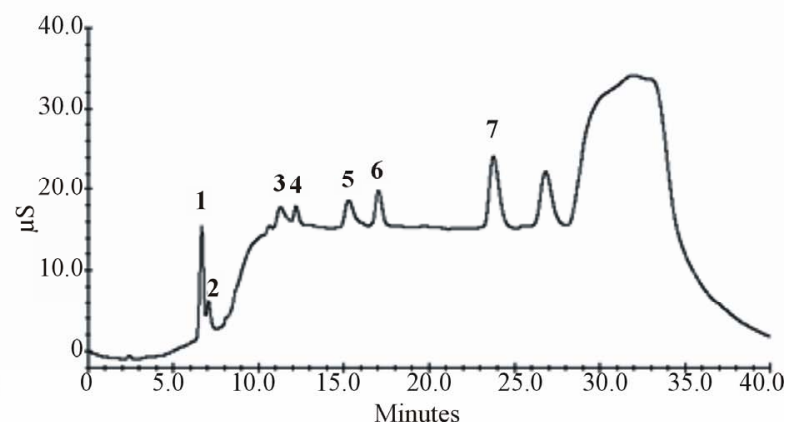

(d)

Figure 4. Chromatograms comparison between spiked samples (lactic acid $20.0 \mathrm{mg} \cdot \mathrm{kg}^{-1}$, acetic acid $20.0 \mathrm{mg} \cdot \mathrm{kg}^{-1}$, sorbic acid $400.0 \mathrm{mg} \cdot \mathrm{kg}^{-1}$, nitrites $20.0 \mathrm{mg} \cdot \mathrm{kg}^{-1}$, benzoic acid $200 \mathrm{mg} \cdot \mathrm{kg}^{-1}$, nitrates $20.0 \mathrm{mg} \cdot \mathrm{kg}^{-1}$, phosphates $20.0 \mathrm{mg} \cdot \mathrm{kg}^{-1}$ ) and not-spiked: Not-spiked semi-hard cheese (a); Spiked semi-hard cheese (b); Not-spiked hard cheese (c); Spiked hard cheese (d). 
able residues of nitrates in cheeses was already reported by several authors [28-32]. Lactic acid and phosphates were quantified in the ranges $40.3-162.1 \mathrm{mg} \cdot \mathrm{kg}^{-1}$ and $17.3-71.4 \mathrm{mg} \cdot \mathrm{kg}^{-1}$ respectively.

\section{Conclusions}

In this work, an analytical method for the determination of seven food additives (sorbic acid, benzoic acid, lactic acid, acetic acid, nitrites, nitrates and phosphates) by ion chromatography coupled with suppressed conductivity detection, was developed, validated and applied for the analysis of different types of cheeses (mozzarella cheese, cheese spread, semi-hard and hard cheese).

The optimisation of sample extraction/purification procedure together with the development of a suitable gradient elution allowed an optimal recovery of each analyte, the removal of the most important interfering compounds, a good resolution of analytes towards endogenous interfering peaks and a good retention times repeatability.

Through a validation procedure, carried out by following an in-house validation model according to European Regulations, it was possible to evaluate the most important validation parameters. These results, expressed in terms of linearity, detection limits (LOD and LOQ), selectivity, accuracy (precision and recovery), ruggedness and measurement uncertainty, demonstrated that the method is well suited to satisfy the demands for accurate confirmation analyses of seven food additives in cheeses, with a simple and fast sample preparation, a rapid analytical response, which is especially valuable in official check analyses and in monitoring schemes.

\section{REFERENCES}

[1] P. F. Fox, P. L. H. Mc Sweeney and C. M. Lynch, "Significance of Non-Starter Lactic Acid Bacteria in Cheddar Cheese," Australian Journal of Dairy Technology, Vol. 53, 1998, pp. 83-90.

[2] Commission Regulation, "Regulation (EC) No. 1129/ 2011 of 11 November 2011 Amending Annex II to Regulation (EC) No 1333/2008 of the European Parliament and of the Council by Establishing a Union List of Food Additives," Official Journal of the European Communities, 2011, pp. L295/1-177.

[3] S. Bahruddin, B. Fazlul, I. S. Muhammad, A. Kamarudzaman and M. T. Khairuddin, "Simultaneous Determination of Preservatives (Benzoic Acid, Sorbic Acid, Methylparaben and Propylparaben) in Foodstuffs Using High-Performance Liquid Chromatography," Journal of Chromatography A, Vol. 1073, No. 1-2, 2005, pp. 393397. http://dx.doi.org/10.1016/j.chroma.2004.10.105

[4] R. F. Witter, E. H. Newcomb and E. Stotz, "The Oxidation of Hexanoic Acid and Derivatives by Liver Tissue in
Vitro," The Journal of Biological Chemistry, Vol. 185, No. 2, 1950, pp. 537-548.

[5] H. J. Deuel, R. Alfin-Slater, C. S. Weil and H. F. Smyth, "Sorbic Acid as a Fungistatic Agent for Foods. I. Harmlessness of Sorbic Acid as a Dietary Component," Food Research, Vol. 19, No. 1, 1954, p. 1.

[6] R. J. Feldmann and H. I. Maibach, "Absorption of Some Organic Compounds through the Skin in Man," Journal of Investigative Dermatology Vol. 54, 1970, pp. 399-404. http://dx.doi.org/10.1111/1523-1747.ep12259184

[7] US FDA (United States Food and Drug Administration), "GRAS (Generally Recognized as Safe) Food Ingredients: Benzoic Acid and Sodium Benzoate," Food and Drug Administration, Washington, DC, 1972.

[8] F. Feillet and J. V. Leonard, "Alternative Pathway Therapy for Urea Cycle Disorders," Journal of Inherited Metabolic Disease, Vol. 21, No. 1, 1998, pp. 101-111.

[9] WHO (World Health Organization), "Concise International Chemical Assessment Document No. 26. Benzoic Acid and Sodium Benzoate," Geneva, Switzerland, 2000.

[10] M. G. El-Ziney, "CG-MS Analysis of Benzoate and Sorbate in Saudi Dairy and Food Products with Estimation of Daily Exposure," Journal of Food Technology, Vol. 7, No. 4, 2009, pp. 127-134.

[11] FAO/WHO (Food and Agriculture Organization of the United Nations/World Health Organization), "Toxicological Evaluation of Certain Food Additives," 67th Meeting of the 435 Joint FAO/WHO Expert Committee on Food Additives (JECFA), 20-29 June 2006, Rome.

[12] M. Iammarino, A. Di Taranto, M. Muscarella and C. Palermo, "Survey of Benzoic Acid in Cheeses: Contribution to the Estimation of an Admissible Maximum Limit," Food Additives and Contaminants: Part B, Vol. 4, No. 4, 2011, pp. 231-237.

http://dx.doi.org/10.1080/19393210.2011.620355

[13] A. M. Fan and V. E. Steinberg, "Health Implications of Nitrate and Nitrite in Drinking Water: An Update on Methemoglobinemia Occurrence and Reproductive and Developmental Toxicity," Regulatory Toxicology and Pharmacology, Vol. 23, No. 1, 1996, pp. 35-43. http://dx.doi.org/10.1006/rtph.1996.0006

[14] G. M. McKnight, C. W. Duncan, C. Leifert and M. H. Golden, "Dietary Nitrate in Man: Friend or Foe?" British Journal of Nutrition, Vol. 81, No. 5, 1999, pp. 349-358. http://dx.doi.org/10.1017/S000711459900063X

[15] O. Matteucci, G. Diletti, V. Principe, E. Di Giannatale, M. M. Marconi and G. Migliorati. "Due casi di Metaemoglobinemia Acuta da Sospetto Avvelenamento da Sodio Nitrito," Veterinaria Italiana, Vol. 44, No. 2, 2008, pp. 439-445.

[16] M. C. Archer, "Mechanisms of Action of N-Nitroso Compounds," Cancer Surveys, Vol. 8, 1989, pp. 241-250.

[17] Commission Regulation, "Regulation (EC) No. 1169/ 2011 of 25 October 2011 on the Provision of Food Information to Consumers, Amending Regulations (EC) No 1924/2006 and (EC) No 1925/2006 of the European Parliament and of the Council, and Repealing Commission 
Directive 87/250/EEC, Council Directive 90/496/EEC, Commission Directive 1999/10/EC, Directive 2000/13/ EC of the European Parliament and of the Council, Commission Directives 2002/67/EC and 2008/5/EC and Commission Regulation (EC) No 608/2004. Official Journal of the European Communities, 2011, pp. L304/ 18-63.

[18] M. S. Norma, J. Steinhardt Bour, M. S. Barbara, A. Soullier and M. B. Zemel, "Effect of Level and Form of Phosphorus and Level of Calcium Intake on Zinc, Iron and Copper Bioavailability in Man," Nutrition Research, Vol. 4, No. 3, 1984, pp. 371-379. http://dx.doi.org/10.1016/S0271-5317(84)80098-6

[19] M. C. Carey, "Pathogenesis of Gallstones," Recenti Progressi in Medicina, Vol. 83, No. 7-8, 1992, pp. 379-391.

[20] Commission Regulation, "Regulation (EC) No. 882/2004 of the European Parliament and of the Council of 29 April 2004," Journal of the European Communities, 2004, pp. L165,1-141.

[21] Commission Decision, "Decision (EC) No. 657/2002 of 12 August 2002 Implementing Council Directive 96/23 /EC Concerning the Performance of Analytical Methods and the Interpretation of Results," Journal of the European Communities, 2002, L221,8-36.

[22] E. J. C. Miller and J. N. Miller, "Statistics for Analytical Chemistry," 3rd Edition, Ellis Horwood PTR Prentice Hall, New York, 1993, p. 115.

[23] W. J. Youden and E. H. Steiner, "Statistical Manual of the AOAC-Association of the Official Analytical Chemists," AOAC-I, Washington DC, 1975.

[24] E. Hund, D. L. Massart and J. Smeyers-Verbeke, "Operational Definitions of Uncertainty" Trends Analytcal Chemistry, Vol. 20, No. 8, 2001, pp. 394-406. http://dx.doi.org/10.1016/S0165-9936(01)00089-9
[25] Dionex Corporation, "Product Manual for IonPac ${ }^{\circledR}$ AS11HC IonPac ${ }^{B}$ AG11-HC," Document No. 031333-07, Sunnyvale, 2008.

[26] F. Toldrà, "Handbook of Meat Processing," John Wiley \& Sons, Blackwell Publishing, New York, 2010. http://dx.doi.org/10.1002/9780813820897

[27] L. Brüggemann, W. Quapp and R. Wennrich, "Test for Non-Linearity Concerning Linear Calibrated Chemical Measurements," Accreditation and Quality Assurance, Vol. 11, No. 12, 2006, pp. 625-631. http://dx.doi.org/10.1007/s00769-006-0205-x

[28] M. Iammarino, A. Di Taranto and M. Cristino, "Endogenous Levels of Nitrites and Nitrates in Wide Consumption Foodstuffs: Results of Five Years of Official Controls and Monitoring," Food Chemistry, Vol. 140, No. 15, 2013, pp. 763-771. http://dx.doi.org/10.1016/j.foodchem.2012.10.094

[29] M. Iammarino, A. Di Taranto, M. Muscarella and C. Palermo, "Assessment of Natural Levels of Substances with Preservative Effects in Dairy Products," In: H. Castelli and L. du Vale, Eds., Handbook on Cheese, Production, Chemistry and Sensory Properties, Nova Publisher Inc., New York, 2013, pp. 559-571.

[30] L. J. Schuddeboom, "Nitrates and Nitrites in Foodstuffs," Council of Europe, Strasbourg, 1993.

[31] A. Topçu, A. A. Topçu, I. Saldamli and M. Yurttagül, "Determination of Nitrate and Nitrite Content of Turkish Cheeses," African Journal of Biotechnology, Vol. 5, No. 15, 2006, pp. 1411-1414.

[32] L. Tudor, E. Mitrânescu, L. Tudor and F. Furnaris, “Assessment of Nitrate and Nitrite Content of Romanian Traditional Cheese," Lucrâri Stiintifice Medicinâ Veterinariâ, Timisoara, XL, 2007. 